\title{
Attrition in the Indian BPO sector: Role of compensation and opportunity to advancement on employee's intention to quit
}

\author{
Akanksha Jain \\ Assistant Professor, Dept. of Commerce, PGDAV College, Nehru Nagar, University of Delhi, New Delhi, India
}

*Corresponding Author:

Email: mailtoakankshajain@gmail.com

\begin{abstract}
Human capital is the most crucial resource on which the BPO industry in India depends. However, it is plagued by this never ending problem of employee attrition. Whenever a well-trained and well-adapted employee leaves the organization, it creates a vacuity. The organization loses a skilled, trained, and essential resource. Consistent employee attrition not only leads to an increase in tangible cost but also includes an intangible or "hidden" cost associated with it.

Purpose: This study intends to study the impact of tangible factor like compensation and an intangible factor like opportunity for advancement on an employee's intention to quit.

Research Design: Employee intention to quit, employees satisfaction from compensation levels and opportunity for advancement were measured using 5-point Likert scale. Statistical techniques such as, correlation analysis, Principal component analysis, descriptive analysis etc were used for understanding the data and analysis.

Results: A study of the statistical output reveals that both compensation and opportunity for advancement factors play a significant role in influencing an employee's intention to quit. Although opportunity for advancement is a major factor which plays a more significant role than compensation.
\end{abstract}

Keywords: Employee attrition, Compensation, Opportunity for advancement.

\section{Introduction}

Employee attrition (Abassi et al., 2000), also called turnover is the rotation of workers around the labour market between firms, jobs and occupations and between the states of employment and unemployment. Further, Price (1977), defines attrition as "The ratio of the number of organizational members who have left during the period being considered divided by the average number of people in that organization during the period". Employee turnover takes place due to various reasons like retirement, resignation, sickness, death or for personal reasons. Factors that leads to an employee quitting an organisation can be varied ranging from higher pay expectation, lack of job security, lack of career advancement options to differences among coworkers etc.

Powered by revolutionary technologies and dramatically changing markets, the intense global competition is creating a turbulent atmosphere in which the Indian BPO (business process outsourcing) industry must operate and prosper. This competition is two-fold; new global industry participants on one side and the experienced domestic industry challengers on the other. This competition intensifies in the dynamic global markets, as the strategies of challenging firms are uncontrollable external forces, leaving the internal management of strategic assets as the only way to create sustained competitive advantage. Thus, the management and retention of internal strategic asset i.e., the human capital is of key strategic advantage to the BPO industry.

BPO industries are trying to retrospect in their human resource strategies and find ways to avert high rates of employee attrition. There is a dire need to understand the reasons for an employee's attrition or his intention to quit an organisation in the first place. This study is aimed in this direction. This study focusses on the impact of tangible factor like compensation and an intangible factor like opportunity for advancement on an employee's intention to quit.

\section{Objectives}

The present study is carried out with the following objectives.

1. Statistically determining whether compensation is a significant variable in an employee's decision to Quit an organisation or not.

2. Statistically determining the significance of the variable, opportunity for advancement, in respect of an employee's intention to quit in BPO industry.

\section{Review of Literature}

Many researchers across the world has conducted research on the concept of employee attrition. Though its not possible to present all of them an attempt to present a few has been made here.

Porter LW, Steers RM, Mowday RT, Boulian PV (1974)

Porter LW, Steers RM, Mowday RT, Boulian PV (1974) provides a reports about the variations in organizational commitment and job satisfaction, as leading to subsequent attrition in a sample of psychiatric technician trainees. With the passage of time, organizational commitment measures proved to be a better predictor of turnover, and job satisfaction failed to predict turnover.

Mobley, W.H (1977) 
Conducted a study on "intermediate linkages in the relationship between job satisfaction and employee turnover" he propounded that although it is clear that the relationship between job satisfaction and turnover is significant and consistent, it is not very strong. The author suggests that it is probable that other variables mediate the relationship between job satisfaction and the act of quitting. He found, the key variable is the concept of behavioural intentions. The model presented is one of the first to propose the role of intentions to quit in the turnover process. (1982)

Dalton, D.R., Todor, W.D., \& Krackhardt, D.M

Conducted a study on "Turnover overstated: A functional taxonomy", this article provides the perspective of attrition from a different angle. The researcher here said that attrition within limits is good for an organisation. The authors hold that recommendation for re-hire is an adequate proxy for "good" (functional versus dysfunctional) turnover.

Jackofsky, E.F (1984)

Conducted a study on "Turnover and job performance: An integrated process model" the key contribution of this article is the integration of job performance into predominant process models of turnover.

Ferris, G.R (1985)

The contributions of average exchange and leadermember exchange (LMX) to explaining variance in employee turnover were examined in an investigation designed to constructively replicate a study by Graen, Liden, and Hoel (1982).

Abelson, M.A (1987)

Conducted a study on "Examination of avoidable and unavoidable turnover" with the objective of study about turnover. Past research has suggested that workers leave either voluntarily or involuntarily. In this article, the author holds that this approach excludes some involuntary departures from analysis, while treating all people who leave voluntarily as being similar.

Dalton, Krackhardt, and Porter's (1981) suggested taxonomy of avoidable and unavoidable turnover, this article examines whether the taxonomy aids in the analysis of turnover. The key finding from this research is that unavoidable departures and retentions did not significantly differ on four variables: Commitment, satisfaction, job tension, and withdrawal cognitions. These findings suggest that researchers should consider the circumstances of job quits when analyzing the causes of employee turnover.

\section{Compensation}

Compensation is the total amount of the monetary and non-monetary pay provided to an employee by an employer in return for work performed as required. It is basically a blend of money and in kind benefits given to an employee for the services he has rendered. Essentially, it's a combination of the value of one's pay, bonuses, health insurance, and any other perk one may receive, such as free lunches, free events, and parking. Compensation also includes payments such as bonuses, profit sharing, overtime pay, recognition rewards and checks, and sales commission. Compensation can also include non-monetary perks such as a company-paid car, stock options in certain instances, company-paid housing, and other non-monetary, but taxable, income items. It's not in the best interests of an employer to have disgruntled, unhappy employees who feel they are underpaid. Thus, it implies that offering fair market compensation with generous benefits should help the employer get a thriving, contributing workforce in sync with the business aims and needs. But a number of studies have shown that compensation does not have a long-term motivational effect (Furnham, 2006). Nor does it necessarily increase productivity. However, it has also been observed that lack of adequate pay does lead to demotivation and employee leaving the organisation for better venues. Thus, if pay does not meet expectations or there is a disparity, employee motivation and performance is negatively affected and an employee shall not hesitate to quit if he gets another offer. To prove the same, we formulate the hypothesis:

H1: Employee's compensation, have a significant and inverse relation with an employee's intention to quit an organization.

\section{Opportunity for Advancement}

Career advancement is one of the most important elements for employee satisfaction and retention at a company. According to Victor Lipman of Forbes, clear opportunities for advancement are an "especially powerful" employee motivator. Many research works, in western countries, have shown a positive relation between opportunities for advancement and employee retention. Consequently we can say that, opportunities for advancement induces a person to perform better and contribute more towards organisational goals, lowering the degree of intention to quit. But does this hold true for the Indian BPO sector also, which has been plagued with huge amount of attrition. To determine the same, we formulate the hypothesis:

H2: Opportunity for advancement, have a significant and inverse relation with an employee's intention to quit an organization.

\section{Research Methodology}

Based on the hypothesis formulated a questionnaire was developed to gather data on employee's intention to quit. Employee's level of satisfaction from his compensation package and from the opportunities for advancement in the organisation were studied in conjunction with his intention to quit to establish the relationship between them. The questionnaire was split into three sections. Each section contained items measuring different variables. The items of the first section measured the demographic variables, like 
gender, level in management hierarchy, qualification etc. the second section measured the independent variable that is the compensation and opportunity for advancement. The last section measure the dependent variable that being intention to quit. The instrument for each variable is developed based on the work of established researchers from previous studies. Items are measured using five-point Likert scales, with 1 representing strongly disagree to 5 representing strongly agree.

Further, the survey questionnaire was administered to a specific number of BPO companies. Interviews was conducted either face to face or online with the employees. Interviews with employees was conducted with the intention to understand the significance of advancement opportunities and compensation with respect to the employees intention to quit.

The survey data, so collected was than processed and analysed using statistical techniques such as, correlation analysis, principal component analysis, descriptive analysis etc. The results were thus studied and inferences derived.

\section{Descriptive Statistics: Demographics}

The descriptive statistics and frequencies for demographics in the overall sample are shown in Table 1 .

Table 1: Gender

\begin{tabular}{|l|c|c|c|c|}
\hline & Frequency & Percent & Valid Percent & Cumulative Percent \\
\hline Male & 260 & 65.0 & 65.0 & 65.0 \\
\hline Female & 140 & 35.0 & 35.0 & 100.0 \\
\hline Total & 400 & 100.0 & 100.0 & \\
\hline
\end{tabular}

Of the total of 400 respondents, the sample has 65 percent male (260) and 35 percent female (140) respondents. In the early stages of BPO industry the females to male ratio was very low. Although the number of females, in the BPO industry has increased over the years, but still they do not stand equal to the population of men. As per a survey on gender inclusivity conducted by HR consulting firm Mercer and IT association, Nasscom. The number of women working in the IT-BPO sector grew 60 percent in the last two years. The Nasscom survey further, mentioned that India has the largest number of working women in any single country in the world, which can be partly attributed to the growth of the IT-BPO industry.

Table 2. Managerial Position

\begin{tabular}{|l|c|c|c|c|}
\hline & Frequency & Percent & Valid Percent & Cumulative Percent \\
\hline Junior Staff & 272 & 68.0 & 68.0 & 68.0 \\
\hline Middle Management & 92 & 23.0 & 23.0 & 91.0 \\
\hline Senior Management & 36 & 9.0 & 9.0 & 100.0 \\
\hline Total & 400 & 100.0 & 100.0 & \\
\hline
\end{tabular}

Exploring the data on employees by their managerial position reveals that 68 percent of respondents are junior managers while the rest 32 percent are middle level or senior level managers. The expectations and aspirations of employees working at different levels of management hierarchy has been proved to be different in various previous research works. Thus, the factors leading to satisfaction and thus intention to quit may vary for different level of employees.

Exploring the sample on the basis of their educational qualification reveals that around $80 \%$ of the sample size have a bachelor degree and are thus graduates in their respective fields. This outcome was expected as the Indian BPO relies heavily on direct recruitment of graduate or post graduate students from their respective colleges. Further, $20 \%$ are post graduates or have higher qualifications. Thus, all the respondents are mature adults above the age of 18 , capable of forming informed judgment.

\section{Descriptive Statistics: Variables}

The descriptive statistics for each of the items in the questionnaire are shown below:

Table 3: Compensation

How satisfied am I with this aspect of my job: My pay and amount of work I do

\begin{tabular}{|l|c|c|c|c|}
\hline & Frequency & Percent & Valid Percent & Cumulative Percent \\
\hline Not satisfied at all & 36 & 9.0 & 9.0 & 9.0 \\
\hline Somewhat satisfied & 176 & 44.0 & 44.0 & 53.0 \\
\hline Satisfied & 144 & 36.0 & 36.0 & 89.0 \\
\hline Very satisfied & 44 & 11.0 & 11.0 & 100.0 \\
\hline Total & 400 & 100.0 & 100.0 & \\
\hline
\end{tabular}


In Table 3, the factor "compensation" is measured. Here, the respondent determines his level of job satisfaction derived from the amount of compensation he get from his work. Examination of the data tells us that out around $89 \%$ of the respondents are just satisfied or not very satisfied by their amount of compensation, only about $11 \%$ says they are happy with their pay.

Table 4: Advancement

\begin{tabular}{|l|c|c|c|c|}
\hline \multicolumn{5}{|c|}{ How satisfied am I with this aspect of my job: The chances for advancement on this job } \\
\hline & Frequency & Percent & Valid Percent & Cumulative Percent \\
\hline Not satisfied at all & 44 & 11.0 & 11.0 & 11.0 \\
\hline Somewhat satisfied & 68 & 17.0 & 17.0 & 28.0 \\
\hline Satisfied & 100 & 25.0 & 25.0 & 53.0 \\
\hline Very satisfied & 172 & 43.0 & 43.0 & 96.0 \\
\hline Extremely satisfied & 16 & 4.0 & 4.0 & 100.0 \\
\hline Total & 400 & 100.0 & 100.0 & \\
\hline
\end{tabular}

In Table 4, the factor "Advancement" is measured. Here, the respondent determines his level of job satisfaction derived from the opportunities one get for advancement on his job. Descriptives of the data shows that a $43 \%$ of the respondents are very satisfied with the opportunities for advancement, while around 44 respondents i.e. $11 \%$ feels the job does not make use of their abilities fully.

\section{Pearson Product-Moment Correlation}

The relationship between compensation and opportunity for advancement and the intention to quit was investigated using Pearson product-moment correlation coefficient.

Table 5: Correlation among the extrinsic and intrinsic job satisfaction and intention to quit

\begin{tabular}{|l|c|c|c|}
\hline \multirow{4}{*}{$\begin{array}{c}\text { QC__1. If I have my own } \\
\text { way, I will be working for } \\
\text { my current employer 12 } \\
\text { months from now }\end{array}$} & $\begin{array}{c}\text { QC_2. I } \\
\text { frequently think } \\
\text { of quitting my job }\end{array}$ & $\begin{array}{c}\text { QC_3. I am } \\
\text { planning to search } \\
\text { for a new job in the } \\
\text { next 12 months }\end{array}$ \\
\hline \multirow{2}{*}{$\begin{array}{c}\text { Compensation (My pay and } \\
\text { amount of work I do) }\end{array}$} & Pearson Correlation & .302 & -.317 \\
\cline { 2 - 4 } & Sig. (2-tailed) & 0.000 & 0.000 \\
\cline { 2 - 4 } & $\mathrm{N}$ & 400 & 400 \\
\hline \multirow{2}{*}{$\begin{array}{l}\text { Advancement (Chances for } \\
\text { advancement on this job) }\end{array}$} & Pearson Correlation & .469 & -.502 \\
\cline { 2 - 4 } & Sig. (2-tailed) & 0.000 & 0.000 \\
\cline { 2 - 4 } & $\mathrm{N}$ & 400 & 400 \\
\hline
\end{tabular}

Table 5, shows the Pearson Correlation amongst the variables compensation, opportunity for advancement and the intention to quit.

\section{Result}

As can be seen from the table 5 that compensation, opportunity for advancement have a $\mathrm{p}$ value less than .05 . Thus, this result indicate that both compensation and opportunity for advancement have a significant influence on an employee's intention to quit.

Inferences from Result: In this study, we are considering a 5\% level of significance, thus if the $p$ value i.e. the sig. ( 2 tailed) value for any independent variable (compensation and opportunity for advancement factors) is greater than .05 ( $\mathrm{p}>.05)$, than that variable shall be considered to be having an insignificant influence on the dependent variable, i.e. intention to quit. As can be seen from the table 5 that compensation, opportunity for advancement have a $\mathrm{p}$ value less than .05. Thus, indicating that both compensation and opportunity for advancement have a significant influence on an employee's Intention to quit. Therefore we can infer that, if compensation is not at par with the work involved or in conjunction with colleagues at same level it may lead to an dissatisfied employee, who may plan to quit the organisation. Further, if there is a lack of opportunities for advancement an employee will feel stagnant and monotonous, and thus he may quit in search of better opportunities. However, it has been observed that compensation is more significant a factor for junior level employees, even with less opportunities of advancement, a good compensation holds them to the job. On the other hand at senior levels of managerial positions, opportunities of advancement becomes more significant factor, a little less compensation does not lead to attrition if there are enough growth opportunities. Thus, the results are seen to satisfy the Maslow need hierarchy theory also. At junior level there is a greater need for finance and compensation is observed to be a more driving factor in intention to quit, while at higher levels with self-actualisation needs, advancement has been observed to become a stronger factor for intention to quit. 


\section{Conclusion}

The objective of this research is to determine, the impact of compensation and opportunity for advancement to an employee's intention to quit in an industry characterized by a high degree of voluntary attrition. A study of the statistical output reveals that both compensation and opportunity for advancement factors play a significant role in influencing a person's intention to quit. Although opportunity for advancement factor play a more significant role than compensation. According to Herzberg theory compensation is an extrinsic factor. Compensation is basically a nondissatisfier, implying the non-existence or inequality in compensation would make an employee dissatisfied in the organisation and thus, he shall surely quit the organisation. But, suitable and equal pay will not necessarily motivate him to perform better. While, opportunity for advancement, will not only induce a person to stay but also motivate him to perform better.

\section{References}

1. Abraham SE, Friedman BA, Thomas RK. The impact of union membership on intent to leave: Additional evidence on the voice face of unions. Employee Responsibilities and Rights Journal. 2005;17(4):201-13.

2. Anuna MN. Determinants of job satisfaction and job dissatisfaction of academic administrators in Texas public universities.

3. Atchison T, Lefferts EA. The prediction of turnover using Herzberg's job satisfaction technique. Personnel Psychology. 1972;25(1):53-64.

4. Arnold HJ, Feldman DC. A multivariate analysis of the determinants of job turnover. Journal of applied psychology. 1982;67(3):350.

5. Baylor KM. Building competitive advantage with contemporary retention strategies. Annual-San DiegoPfeiffer And Company-. 2007;3:3.

6. Baylor KM. The influence of intrinsic and extrinsic job satisfaction factors and affective commitment on the intention to quit for occupations characterized by high voluntary attrition. Nova Southeastern University; 2010.

7. Bockman VM. The Herzberg controversy. Personnel Psychology. 1971;24(2):155-89.

8. Boles J, Madupalli R, Rutherford B, Andy Wood J. The relationship of facets of salesperson job satisfaction with affective organizational commitment. Journal of Business \& Industrial Marketing. 2007;22(5):311-21.

9. Carmeli A, Shalom R, Weisberg J. Considerations in organizational career advancement: what really matters. Personnel Review. 2007;36(2):190-205.

10. Carson PP, Carson KD, Birkenmeier B, Toma AG. Looking for loyalty in all the wrong places: A study of union and organization commitments. Public Personnel Management. 2006;35(2):137-51.

11. Caston RJ, Braito R. A Specification Issue in Job Satisfaction Research: What Happens to Job Satisfaction Models When Workers Place High Value on Increasing Their Satisfaction?. Sociological Perspectives. 1985;28(2):175-97.

12. Ünal ÖF. Relationship between organizational commitment and ethical climate: The mediating role of job satisfaction dimensions (a study in a group of companies in Turkey). Journal of WEI Business and Economics. 2012;1(1):92-105.
13. Chiu RK, Francesco AM. Dispositional traits and turnover intention: Examining the mediating role of job satisfaction and affective commitment. International Journal of Manpower. 2003;24(3):284-98.

14. Dole C, Schroeder RG. The impact of various factors on the personality, job satisfaction and turnover intentions of professional accountants. Managerial Auditing Journal. 2001;16(4):234-45.

15. Firth L, Mellor DJ, Moore KA, Loquet C. How can managers reduce employee intention to quit?. Journal of managerial psychology. 2004;19(2):170-87.

16. Freed DE. Material benefits, advancement, or fulfillment: A study into the causes and predictors of job satisfaction based on how people view their work. Journal of Applied Management and Entrepreneurship. 2003;8(4):116.

17. Locke EA, Latham GP. Work motivation and satisfaction: Light at the end of the tunnel. Psychological Science. 1990;1(4):240-6.

18. Maslow AH. A theory of human motivation. Psychological review. 1943;50(4):370.

19. Meyer JP, Allen NJ. Commitment in the workplace. Thousand Oaks. Google Scholar. 1997.

20. Meyer JP, Allen NJ, Smith CA. Commitment to organizations and occupations: Extension and test of a three-component conceptualization.

21. Journal of applied psychology. 1993;78(4):538.

22. Meyer JP, Stanley DJ, Herscovitch L, Topolnytsky L. Affective, continuance, and normative commitment to the organization: A meta-analysis of antecedents, correlates, and consequences. Journal of Vocational Behavior. 2002;61(1):20-52.

23. Miller S. Workers' engagement levels drop, along with their expectations. HR Magazine. 2009;54:16.

24. Myers MS. Who are your motivated workers?. Harvard Business Review Reprint Service; 1964 Jan 1. 